OPEN ACCESS

Edited by:

Andy Townsend,

University of Nottingham,

United Kingdom

Reviewed by:

Francis Thaise A. Cimene, University of Science and Technology of Southern Philippines, Philippines Ragad Tawafak,

Al-Buraimi University College, Oman

*Correspondence:

Georgios Tsaramirsis gtsaramirsis@hct.ac.ae

Specialty section:

This article was submitted to Leadership in Education, a section of the journal

Frontiers in Education

Received: 08 March 2021 Accepted: 18 November 2021 Published: 09 December 2021

Citation: Khan FQ, Buhari SM, Tsaramirsis G and Rasheed S (2021) A Study of Faculty Retention Factors in Educational Institutes in Context With ABET.

Front. Educ. 6:678018. doi: $10.3389 /$ feduc.2021.678018

\section{A Study of Faculty Retention Factors in Educational Institutes in Context With ABET}

\author{
Fazal Qudus Khan ${ }^{1}$, Seyed M. Buhari ${ }^{1}$, Georgios Tsaramirsis ${ }^{2 *}$ and Saim Rasheed ${ }^{1}$ \\ ${ }^{1}$ Department of Information Technology, King Abdulaziz University, Jeddah, Saudi Arabia, ${ }^{2} H i g h e r$ Colleges of Technology, Abu \\ Dhabi Women's College, Abu Dhabi, United Arab Emirates
}

A typical higher education institute classically has all the five major constituents, i.e. current students, alumni, faculty members, employers and industrial advisory board. Expectations of the rest of the constituents are fully dependent on the faculty members, as they play a pivotal and backbone role in building up an educational institute, to a high repute. Faculty members provide the knowledge and skills necessary to students, to address market needs. Letting go of skilled, professional and enthusiastic faculty members can have a huge impact on any higher education institution's reputation and in fulfilling the market needs. In this research, we explore the different influencing factors and criteria for retaining teaching staff at schools and higher education institutes. These criteria are then evaluated against Accreditation Board of Engineering and Technology (ABET) accredited institutes criteria data of "faculty" and "Institutional support," to see the impact. Study shows that only very few faculty members leave the institution because of higher student-to-faculty ratio or denial of tenure. Also, most of institutions concentrate on providing reduced number of lecture hours per week to keep their faculty members happy and perform research at the institution. Out of 737 faculty members of 27 institutes included in this study, only $0.54 \%$ faculty members left ABET accredited institutions.

Keywords: ABET, SSR, faculty retention, teachers retention, quality enhancement

\section{INTRODUCTION}

Faculty members of higher education institutions mainly have three major elements in their job description, i.e. teaching, administrative duties and research. Keeping a sound balance of distribution among all the three elements over an academic year, either in a semester-based system or in a yearly based system, is of utmost importance for the job satisfaction of a faculty member. All these three components need time, devotion, dedication, skills and expertise. Teaching the courses which are relevant to the expert area or the domain of the faculty members need to be considered. i.e., subjects that consume less time for preparation. Administrative tasks must be assigned in such a way that the faculty member have prior knowledge, training and know how to do the job. On the other hand, faculty members must be given proper training or instructions or manual via a workshop or a seminar before the assignment of any new task. Research work is solely expertise-based job where a researcher only digs more into the area of interest. However, all the three main tasks mentioned and explained above, needs proper planning for the distribution of a balanced and fair load in any educational institution. Providing a friendly environment wherein faculty members can polish and nurture their skills and knowledge is also considered of great importance. A continuous enhancement in skills, knowledge and experience in terms of teaching and research is a must 
because it will help faculty members to retain their positions because talented and productive employees have always been the center for any organization who can play a significant role in building stronger academic institutes. These institutes who always keep hunting such productive faculty members, in return must implement policies that could potentially support and maintain the retention rate which will contribute to the progress and growth of a characterized work environment, not only for the faculty itself but also for their peers. One of the most important factor for a faculty member to stay in an educational environment may be the status of job, i.e. tenure tracked, permanent, contract based, temporary, adjunct etc. Permanent employees are more relaxed and their retention is expected to be higher than others. On the other hand, contract based and adjunct faculty members usually search for better opportunities. There are several other factors such as opportunities for personal investments and social benefits, immigration policies of the country for life-time planning and children's education. These factors may also play a significant role in retention of faculty members. Solutions to recruit, retain and maintain academic faculty members in Medical Education shows the need to consider various diversified factors (Lo et al., 2020). Specific study towards improved retention of nursing faculty from minority community shows the need to integrate various cross-cultural and peer mentoring into the academic environment (Julion et al., 2019).

The objective of this study is to investigate the criteria and impact of influencing factors on faculty retention and to find any correlation, if exists between Accreditation Board of Engineering and Technology (ABET) and retention. Note that our investigation is not meant to be a generalized framework, rather an observation that may be considered by the faculty members to support in their decision-making process for their careers.

Here we describe the hierarchy of the study. Section 2 presents literature review which is divided into two parts. In the first part, we discuss state-of-the art criteria for retaining teaching staff at educational institutions, while in the second part we will explore the relationship of professional development on teaching staff retention along with data collected from multiple sources. Section 3 presents methodology to explain, how the overall study was carried out, whereas Section 4 presents discussion of results and Section 5 concludes the overall concept.

\section{LITERATURE REVIEW}

Different theories for retention at different transition points exists, such as Ajzen theory (Ajzen, 1991) and transition theory (Anderson, 2011). These theories are considered for studying retention, improvement and research by education experts, researchers and administrators. Limited literature is available for employability measurement, however a study (Heijde and Heijden, 2006) shows assessing the employability of hired people is actually based on supervisor rating of onthe-job performance which is directly linked to professional development (Reynolds et al., 2002). However, it is pertinent to say that employability must be assessed through three ways, i.e. employer interview, observation of actual teaching and through the tools designed for assessing employability attributes (Espinoza et al., 2020). Approximately 20\% of new teachers leave by the end of the year, while $40 \%$ leave by the end of the fifth year (Avalos, 2011). Movers (who switch job) having industrial experience, for them transferring industrial/practical experience to teaching skills is a motivator as a second-career (Mayotte, 2003). Statistical figures from two state-wise datasets, acquired from Texas and Florida in 1999, shows that movers accounted for $47 \%$ of teachers (Kersaint et al., 2007). It is interesting to note that $56 \%$ vacancies were filled by movers who have worthy experiences and only $16 \%$ by fresh graduates whereas $5-50 \%$ of teachers quit/switch their jobs in their first 5 years of career (Schaefer et al., 2012). These numbers seem provoking for many of us but we should remind ourselves that different educational institutes may have different strategies and policies to hire fire and retain faculty members with different skills, backgrounds and varying range of experiences. Here, we present some of the retention criteria from the multiple sources in educational institutes.

\subsection{Retention Factors at Educational Institutes}

A study at US schools examines why teachers leave, plan to remain or resign, and the likelihood of returning of faculty members through Ajzen theory of planned behavior (Ajzen, 1991). Family issues are termed as the most crucial factor in determining the possibility of a faculty member's decision of whether to stay or leave a job. Family, administrative support, joy of teaching, financial support and volume of work are considered as the key stimuli for joining an institution. Firing decisions can be triggered due to less students-teachers ratio and last-minute hiring of underqualified professionals (Kersaint et al., 2007). In another study, on retention factors for local faculty members, due to their low representation in key organizations in Australia, it was found that family support is one of the main factors for any indigenous pre-service teacher (Trimmer et al., 2018).

Educational research and its inapplicability due to cultural factor is alarming. The outcome of educational research is hardly followed by practitioners because the willingness to apply the results is negligible. At the same time, a major concern in educational research is the minimal contribution of researchers to a professional knowledge base. An online discussion forum was implemented to validate the research, however it concluded that it is impractical to generalize all the experimental results conducted at school level due to variety of cultural differences that may vary based on geographical locations. Research and practice of the concluding methods to enhance the quality cannot be applicable in two different cultures (Joram et al., 2020).

An emergent ecological school model was proposed (Zavelevsky and Lishchinsky, 2020) based on an educational 
literature terminology of Novice teacher, which refers to the teachers with three to 5 years of experience. It was found out that the main retention factors are individual (knowledge, skills), interpersonal (relationship with other colleagues), organizational (rules and regulations), community (promoting social norms) and policy (local, state and federal).

Study of elementary teachers' needs suggested that financial benefits, school environment to earn respect and support of students and others at work, and long holidays are some of the factors attracting faculty members to stay in the same workplace. Moral and financial appreciations of work are also considered very encouraging and motivational factors in retention (Cockburn, 2000).

A longitudinal study revealing the complex pattern of changes, over 3 years of second career/movers was performed in which attrition and retention was termed as a big concern for schools and teaching institutions. Administrative tasks, workplace conditions, schools support, mentoring (Professional development) and personal beliefs (perceptions and characteristics) were considered as factors for retention/ attrition in the study (Goodwin et al., 2019).

Teaching needs adequate knowledge and skills that require a proper mechanism of supply and demand and a study was carried out by the principals to elaborate the process of maintaining the supply and demand among schools (Donitsa-Schmidt and Zuzovsky, 2014). Authors have shown that principals employed strategies like overloading the teachers, hiring under or overqualified teachers, and employing temporary teachers for long periods of time to meet the supply and demand requirements and it ended up with low retention rate.

Zhou and Volkwein (2004) studied the factors influencing the retention of all the faculty members including tenured and nontenured. Based on National Study of Postsecondary Faculty (NSOPF-99) dataset, the study reveals that tenured faculty members are influenced by compensation, while non-tenured faculty are influenced by satisfaction with job security. Senior faculty members are expected not to shift job positions. Also, the influence of three factors such as seniority, satisfaction with job security, and satisfaction with compensation are higher than other factors.

Johnsrud and Rosser (2002) studied the reasons behind leaving of a faculty member, at varied academic or administrative positions, from an institution. Study reveals that "morale" defined as "the well-being that an individual or group is experiencing in reference to their work life" is the main cause for leaving an institution. Higher morale can be achieved through the culture in the organization, involvement of faculty members in decision making, feeling of momentum in the organization, and how much a faculty is known within the institution.

Vocational-technical faculty are influenced or attracted towards private industry (Rosser and Townsend, 2006). This study further elaborates that in public community colleges, faculty members are well satisfied with their work environment. Increasing the technical support given to faculty members, improving the library holdings and classroom facilities will improve the retention of faculty members.

Importance of campus life on faculty retention is a wellstudied and reported topic (Anderman et al., 1991; DarlingHammond, 2003; Dee, 2004; Gardner, 2012a; Piercy et al., 2005). Anderman et al. (1991) suggests the importance of supportive and conducive environment for maintaining satisfaction among faculty members. Time commitment (Barnes et al., 1998) along with the knowledge of the faculty about their institution do affect the intention to leave. Therefore, authors have suggested giving emphasis on schedule-based rewards and providing an environment with appropriate stimulus. Recent study has shown the importance of organizational rewards to retain star faculty (Desselle et al., 2021). Borman and Dowling (2008) studied the problem further and suggested that along with work environments, mentoring programs also play an important role for faculty retention. Authors have also suggested a need for an extensive randomized experiments or well-crafted quasi-experiments to have a convincing evaluation. Furthermore, Ponjuan et al. (2011) showed that understanding the feasibility of tenure process encourages the collegial relationships among faculty members. Dissatisfaction about the environment has caused many woman faculty members to leave the institution (Gardner, 2012a). A recent study (Tawafak et al., 2020) has invested the importance of using IT governance towards enhancing academic performance. Factors like graduates' attributes, teaching and assessment methods are to be improved through e-learning systems.

Changes in curriculum, governance and faculty development are common. But these changes should be made in such a way to be attractive towards faculty members (Dee, 2004). Selection of candidates for teaching jobs is influenced by grade scores and interviews. A study (Bowles et al., 2014) suggests the consideration of previous achievements, reasoning skills and social interaction skills as important factors for selection.

Based on all the above factors some are extracted that can potentially affect the retention rate. Some of the factors that can potentially effect the retention are financial benefits, academic reputation of the institution, good working environment, long holidays/time off, work family balance and teaching load. These retention factors are not exhaustive as it is evident from literature that it is very subjective matter and decision making of a faculty member to quit or remain in the job depends on variety of influential reasons and some of them are shown in Figure 1. There may be several other factors that could possibly affect the retention rate.

\subsection{Retention and Professional Development}

Huge investment (millions of dollars) is made for professional development in teaching institutions, to engage teachers in professional development activities and retention (Avalos, 2011). NTE (National teacher examination) scores of PDS (professional 


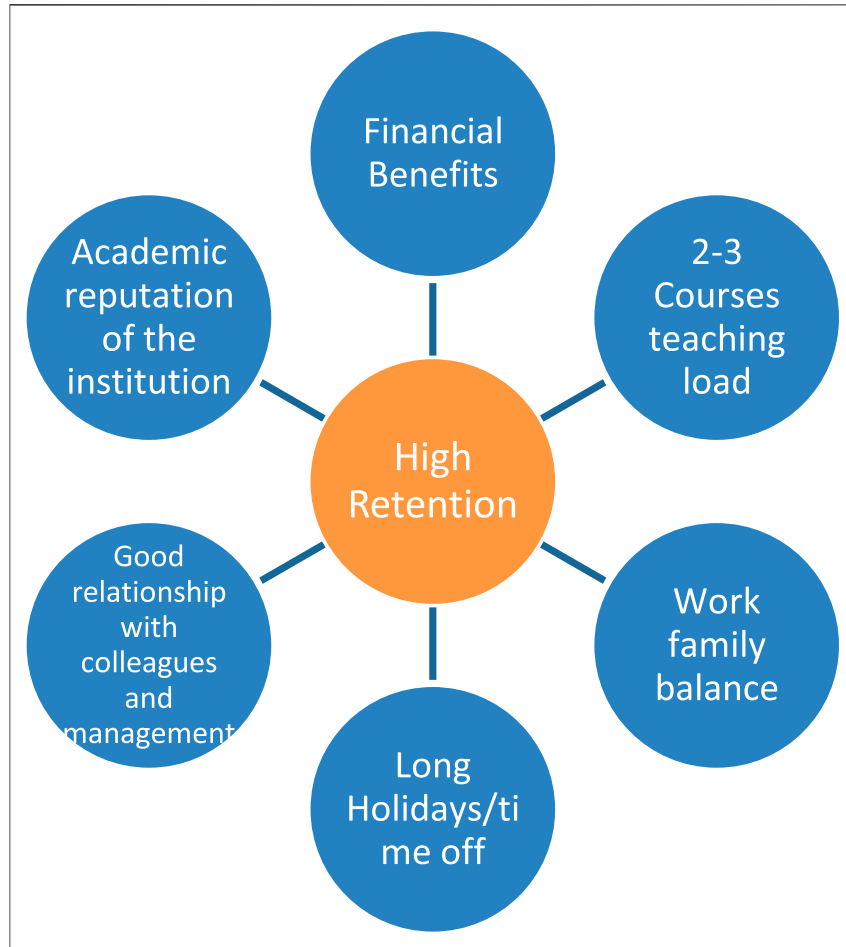

FIGURE 1 | High retention factors.

development schools) and non-PDS (non-professional development schools) suggest no significant difference (Long and Morrow, 1995). A comparison of professional development schools (PDS) and nonprofessional development (non-PDS) schools indicates that professional development has no link to retention of teachers, however it is solely dependent on individual effectiveness (Reynolds et al., 2002). Usually the PD (Professional development) members chosen for professional development training and courses, are the talented faculty. The only edge of PDs over non-PDS is that PDS are more effective in teaching and as observed are rated high by their directors (Reynolds et al., 2002). The effect of professional development is very limited, as its focus is usually not on multiple but on single subject area, intended for small group and a minor part of teaching practice. Appraisal and recognition of work are important factors seen by teachers for their retention (Gore et al., 2017).

The effect of professional development on teacher's career was observed to have good impact on student outcomes but with lesser retention dependability. Teachers see themselves likely to maintain their position progressively when the organization engage them in professional development programs. Professional development is usually for promotion and/or leadership skills enhancement (Coldwell, 2017). Relationship among three factors i.e. distributed leadership, professional collaboration and job satisfaction for school teachers shows that distributed leadership is directly associated with job satisfaction of teachers. Professional collaboration was defined as joint team lecturing, observing other teachers and collaborative professional development, and it was noted that professional development has a direct link with job retention (García Torres, 2019). Teachers training for retention was investigated in three
Chilean universities, considering the socio-economic factor. Study shows that classroom management was considered a top employability factor for hiring of individuals in lower income places, while in higher income places academic knowledge of individuals was a priority influencer. For retention at any place, family was considered as one of the most important factors. Hiring alumni is considered as an aspect to assess the program's success in Chilean universities (Espinoza et al., 2020). A summary of faculty retention factors at different educational institutes is presented in Table 1.

\section{METHODOLOGY}

Retaining qualified professionals for any educational institute is of utmost importance and faculty also considers the available facilities arranged by the institutes in addition to other benefits and resources such as lab equipment and technical resources, supply and demand of their professional needs, official resources, opportunities and arrangement for professional trainings. Institutes following various academic accreditation standards adhere to planning, management and delivery of assessment results in terms of learning outcomes. Focus of accreditation on technology enhancement, student learning outcomes and faculty technology experience is reported (Tawafak et al., 2018).

Such facilities are readily available in most of the well reputed institutes but an institution with ABET accreditation must ensure the availability of all possible required resources for their faculty and students as well because it is a matter of high prestige for the institution, and they try their best efforts to retain the high profile faculty and it plays a role of stimulating factor for faculty to decide either to remain in the position or to quit the job. In other words, both the institution and faculty may be considered necessary and sufficient conditions for each other. It is generally assumed that any institution applying for ABET accreditation must fulfil all the criteria required for the accreditation purpose. We are only interested in two of them i.e., criterion 6, "Faculty" and criterion 8. "Institutional Support."

Criteria 6 states that "Each faculty member teaching in the program must have expertise and educational background consistent with the contributions to the program expected from the faculty member. The competence of faculty members must be demonstrated by such factors as education, professional credentials and certifications, professional experience, ongoing professional development, contributions to the discipline, teaching effectiveness, and communication skills. Collectively, the faculty must have the breadth and depth to cover all curricular areas of the program ${ }^{1}$."

Criteria 8 states that "Resources including institutional services, financial support, and staff (both administrative and technical) provided to the program must be adequate

${ }^{1}$ https://www.abet.org/accreditation/accreditation-criteria/criteria-for-accreditingcomputing-programs-2020-2021/\#GC6 
TABLE 1 | Faculty retention factors at different educational institutes.

\begin{tabular}{|c|c|c|c|c|c|}
\hline S\# & Paper & Data collection & $\begin{array}{l}\text { Factors for } \\
\text { retention and } \\
\text { or/Joining }\end{array}$ & $\begin{array}{l}\text { Institution/ } \\
\text { Workplace of } \\
\text { research } \\
\text { experiment }\end{array}$ & $\begin{array}{l}\text { Factors for } \\
\text { leaving }\end{array}$ \\
\hline 1 & Joram et al. (2020) & Interviews & $\begin{array}{l}\text { 1. Willingness to apply } \\
\text { research } \\
\text { 2. Social/Cultural factor }\end{array}$ & Schools & Not mentioned \\
\hline 2 & Espinoza et al. (2020) & Interviews & $\begin{array}{l}\text { 1. Socio-economical factor } \\
\text { 2. Family factor } \\
\text { 3. Professional development } \\
\text { of teachers }\end{array}$ & Universities & Family factor \\
\hline 3 & Kersaint et al. (2007) & Survey/questionnaire & $\begin{array}{l}\text { 1. Family responsibilities } \\
\text { 2. Financial benefits } \\
\text { 3. Administrative support } \\
\text { 4. Volume of work } \\
\text { 5. Joy of teaching }\end{array}$ & Schools & $\begin{array}{l}\text { 1. Last minute hiring of under qualified } \\
\text { professionals } 2 \text {. student-teacher ratio } 3 \text {. Family } \\
\text { factor }\end{array}$ \\
\hline 4 & $\begin{array}{l}\text { Zavelevsky and Lishchinsky, } \\
\text { (2020) }\end{array}$ & Interviews & $\begin{array}{l}\text { 1. Individual (knowledge, skills) } \\
\text { 2. Interpersonal (relationship } \\
\text { with other colleagues) } \\
\text { 3. Organizational (rules and } \\
\text { regulations) } \\
\text { 4. Community (promoting } \\
\text { social norms) } \\
\text { 5. Policy (local, state and } \\
\text { federal) }\end{array}$ & Schools & $\begin{array}{l}\text { All the factors mentioned for retention if not met } \\
\text { results in changing a person job or quitting a job }\end{array}$ \\
\hline 5 & Trimmer et al. (2018) & Interviews & Family support & University & Low income and family support \\
\hline 6 & Cockburn, (2000) & $\begin{array}{l}\text { Interviews and Survey/ } \\
\text { questionnaire }\end{array}$ & $\begin{array}{l}\text { 1. Financial benefits } \\
\text { 2. School environment } \\
\text { 3. Societal (Respect of } \\
\text { students and colleagues) } \\
\text { 4. Long holidays }\end{array}$ & Elementary schools & Less appreciation (morally and financially) \\
\hline 7 & Goodwin et al. (2019) & Survey/questionnaire & $\begin{array}{l}\text { 1. Administrative tasks } \\
\text { 2. Workplace conditions } \\
\text { 3. Schools support } \\
\text { 4. Mentoring (Professional } \\
\text { development) } \\
\text { 5. Personal beliefs } \\
\text { (perceptions and } \\
\text { characteristics) }\end{array}$ & Schools & $\begin{array}{l}\text { The same factors for retention are mentioned for } \\
\text { attrition }\end{array}$ \\
\hline 8 & Gore et al. (2017) & Interviews & $\begin{array}{l}\text { 1. Professional development } \\
\text { 2. Appraisal and recognition of } \\
\text { work }\end{array}$ & Schools & None \\
\hline 9 & Coldwell, (2017) & Survey/questionnaire & Professional development & Schools and colleges & Lack of Professional development programs \\
\hline 10 & García Torres, (2019) & Survey/questionnaire & $\begin{array}{l}\text { 1. Distributed leadership } \\
\text { 2. Professional collaboration } \\
\text { 3. Organizational culture } \\
\text { 4. Professional development }\end{array}$ & schools & $\begin{array}{l}\text { 1. Lack of Professional development } 2 . \\
\text { Distributed leadership }\end{array}$ \\
\hline 11 & Reynolds et al. (2002) & $\begin{array}{l}\text { Interviews and Survey/ } \\
\text { questionnaire }\end{array}$ & $\begin{array}{l}\text { 1. Individual effectiveness } \\
\text { 2. Professional development }\end{array}$ & Schools & Individual effectiveness \\
\hline 12 & $\begin{array}{l}\text { Donitsa-Schmidt and } \\
\text { Zuzovsky, (2014) }\end{array}$ & - & $\begin{array}{l}\text { Maintaining Supply and } \\
\text { demand ratio }\end{array}$ & Schools & $\begin{array}{l}\text { 1. Overload } \\
\text { 2. Under qualified hiring } \\
\text { 3. Long term temporary contracts }\end{array}$ \\
\hline 13 & Zhou and Volkwein, (2004) & - & $\begin{array}{l}\text { 1. Compensation } \\
\text { 2. Job security } \\
\text { 3. Seniority/age factor }\end{array}$ & $\begin{array}{l}\text { Postsecondary } \\
\text { schools/colleges }\end{array}$ & None \\
\hline
\end{tabular}


TABLE 1 | (Continued) Faculty retention factors at different educational institutes.

\begin{tabular}{|c|c|c|c|c|c|}
\hline S\# & Paper & Data collection & $\begin{array}{l}\text { Factors for } \\
\text { retention and } \\
\text { or/Joining }\end{array}$ & $\begin{array}{c}\text { Institution/ } \\
\text { Workplace of } \\
\text { research } \\
\text { experiment }\end{array}$ & $\begin{array}{l}\text { Factors for } \\
\text { leaving }\end{array}$ \\
\hline 14 & $\begin{array}{l}\text { Johnsrud and Rosser, } \\
\text { (2002) }\end{array}$ & - & $\begin{array}{l}\text { 1. Organization structure } \\
\text { 2. Involvement in decision } \\
\text { making } \\
\text { 3. Feeling of momentum in } \\
\text { organization } \\
\text { 4. How much a faculty is } \\
\text { known in the institution }\end{array}$ & $\begin{array}{l}\text { Mixed academic } \\
\text { institutions }\end{array}$ & 1. Morale 2. Well-being, work life \\
\hline 15 & $\begin{array}{l}\text { Rosser and Townsend, } \\
\text { (2006) }\end{array}$ & - & $\begin{array}{l}\text { 1. Library holding } \\
\text { 2. Classroom facilities }\end{array}$ & Community colleges & None \\
\hline 16 & Anderman et al. (1991) & - & Campus life/environment & academic institutions & None \\
\hline 17 & Gardner, (2012a) & - & Campus life/environment & academic institutions & None \\
\hline 18 & Darling-Hammond, (2003) & - & Campus life/environment & academic institutions & None \\
\hline 19 & Dee, (2004) & - & Campus life/environment & academic institutions & None \\
\hline 20 & Barnes et al. (1998) & - & $\begin{array}{l}\text { 1. Schedule based awards } \\
\text { 2. An environment with } \\
\text { appropriate stimulus }\end{array}$ & academic institutions & $\begin{array}{l}\text { 1. Time commitment } \\
\text { 2. Knowledge of the faculty about the institution }\end{array}$ \\
\hline 21 & $\begin{array}{l}\text { Borman and Dowling, } \\
\text { (2008) }\end{array}$ & - & $\begin{array}{l}\text { 1. Environment } \\
\text { 2. Mentoring programs }\end{array}$ & academic institutions & None \\
\hline
\end{tabular}

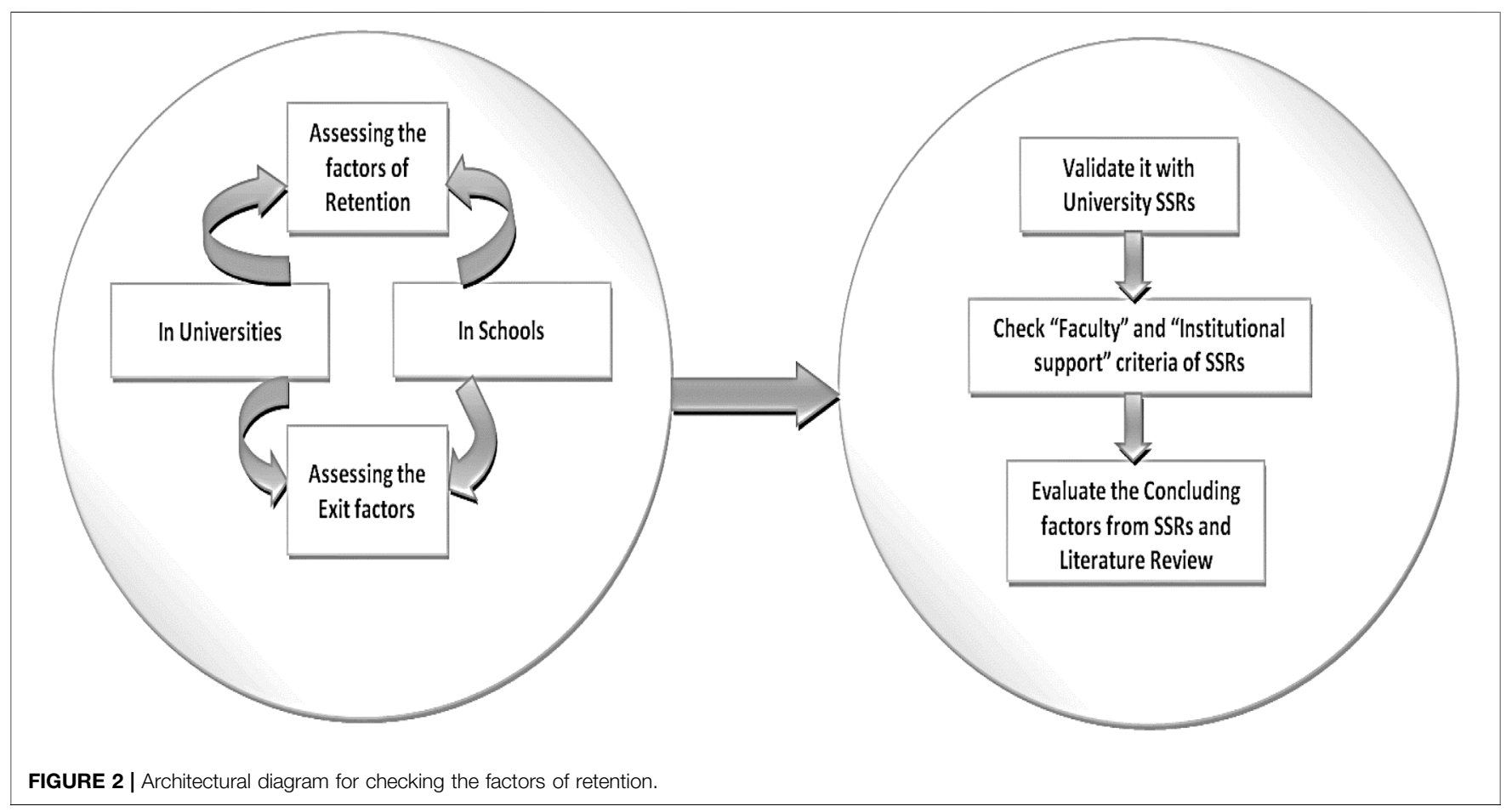

to meet program needs. The resources available to the program must be sufficient to attract, retain, and provide for the continued professional development of a qualified faculty. The resources available to the program must be sufficient to acquire, maintain, and operate infrastructures, facilities and equipment appropriate for the program, and to provide an environment in which student outcomes can be attained2."

${ }^{2} \mathrm{https} / /$ www.abet.org/accreditation/accreditation-criteria/criteria-for-accreditingcomputing-programs-2020-2021/\#GC8 
TABLE 2 | Document analysis (SSR) of 27 ABET accredited institutes for retention factors.

\begin{tabular}{|c|c|c|c|c|c|c|c|c|}
\hline S.No & Date & $\begin{array}{l}\text { Faculty } \\
\text { total }\end{array}$ & $\begin{array}{l}\text { Faculty } \\
\text { PhD }\end{array}$ & $\begin{array}{l}\text { Faculty } \\
\text { tenure }\end{array}$ & Left & $\begin{array}{l}\text { Min faculty/ } \\
\text { Workload } \\
\text { per semester }\end{array}$ & $\begin{array}{l}\text { Max faculty/ } \\
\text { Workload } \\
\text { per semester }\end{array}$ & Faculty/Workload ratio \\
\hline 1 & July 1, 2017 & 7 & 5 & 2 & - & 14 & 16 & - \\
\hline 2 & $\begin{array}{l}\text { June } 27 \\
2014\end{array}$ & 13 & 13 & 6 & - & Adjunct: 18 & Adjunct: 18 & - \\
\hline 3 & June 2011 & 7 & 7 & - & - & 30 units for 9 months & & $\begin{array}{l}60 \% \text { teaching, } 30 \% \text { research, and } 10 \% \\
\text { service }\end{array}$ \\
\hline 4 & $\begin{array}{l}\text { Sept. 27, } \\
2011\end{array}$ & 7 & 6 & 5 & & 2 Courses & 4 Courses & $50 \%$ teaching, $30 \%$ research and $20 \%$ service \\
\hline 5 & $\begin{array}{l}\text { June } 30 \\
2015\end{array}$ & 4 & 4 & 4 & - & - & - & - \\
\hline 6 & $\begin{array}{l}\text { June } 30 \\
2012\end{array}$ & 13 & 13 & - & - & - & - & $\begin{array}{l}50 \% \text { Teach; S/F: } 26.5 \text { Unsustainable } \\
\text { workload }\end{array}$ \\
\hline 7 & $\begin{array}{l}\text { June } 30 \text {, } \\
2014\end{array}$ & 14 & 13 & 13 & $\begin{array}{l}1 \text { (Denied } \\
\text { tenure) }\end{array}$ & - & - & $\begin{array}{l}\text { One course release for new member for three } \\
\text { semesters }\end{array}$ \\
\hline 8 & June 2014 & $4+$ ANY & - & 4 & - & 2 Courses & 3 Courses & - \\
\hline 9 & June 2012 & 38 & 38 & & - & 2 Courses & 5 Courses & - \\
\hline 10 & July 1, 2011 & 4 & 4 & - & - & 3 Courses & & - \\
\hline 11 & July 1, 2008 & 32 & 32 & 15 & - & 2 Courses & & - \\
\hline 12 & $\begin{array}{l}\text { June } 30, \\
2006\end{array}$ & 14 & - & - & 3 left & - & - & S/F: 30.9 (Highest in the area) \\
\hline 13 & July 1, 2015 & 9 & - & - & - & - & - & - \\
\hline 14 & July 1, 2015 & 11 & - & 9 & - & 24 Contact hours & 32 Contact hours & - \\
\hline 15 & June 2012 & 4 & 3 & & - & 12 Credit hours & & - \\
\hline 16 & June 2017 & 6 & - & 4 & - & 3 Courses & & - \\
\hline 17 & $\begin{array}{l}\text { June 30, } \\
2015\end{array}$ & 8 & 8 & - & - & 12 Credit hours & & $\mathrm{S} / \mathrm{F}<30$ \\
\hline 18 & $\begin{array}{l}\text { June } 28 \\
2013\end{array}$ & 7 & 7 & - & - & - & - & - \\
\hline 19 & $\begin{array}{l}\text { June } 25, \\
2012\end{array}$ & 10 & 10 & - & & 2 Courses & 3 Courses & - \\
\hline 20 & - & - & - & - & - & - & - & Adequate \\
\hline 21 & July 1, 2015 & 8 & 8 & - & - & 1 Courses & 2 Courses & - \\
\hline 22 & $\begin{array}{l}\text { June } 28, \\
2016\end{array}$ & 17 & 17 & - & - & 12 Credits & & - \\
\hline 23 & June 2013 & 64 & 64 & - & - & 2 Courses & 3-4 courses & S/F: 16.7 \\
\hline 24 & $\begin{array}{l}\text { June } 30 \\
2013\end{array}$ & 13 & 11 & 9 & - & 3 courses & & - \\
\hline 25 & July 2010 & 12 & - & - & - & - & - & - \\
\hline 26 & July 1, 2014 & 22 & 9 & 15 & - & 1 Course & 2 Courses & S/F: Favorable \\
\hline 27 & $\begin{array}{l}\text { June } 25 \\
2013\end{array}$ & 31 & - & - & - & 1 Course & 2 Courses & - \\
\hline
\end{tabular}

It is self-explanatory by the statements of both criteria that there are strong requirements to be ensured and maintained by the ABET accredited institutes which are needed for retention of faculty members. Such institutes are supposed to demonstrate their best efforts to make sure the presence of retention factors and to avoid those factors that may have negative impact on retention. Hence, we assume that ABET accredited institutes may have high retention rates. This has been the basis of our hypotheses of the study.

Like individual interview, group interview and nominal group technique (NGT), document analysis is a traditional technique of requirement engineering whereby the organization's business documents i.e. written work procedures, forms, reports and existing information systems are given for the requirement gathering purpose. In this research, we have followed document analysis approach for data acquisition which is one of the traditional techniques for requirement engineering to validate our research hypotheses in context with both criteria 6 and 8 i.e. whether the requirements of criteria 6 and 8 have any effect on faculty retention in ABET accredited institutes or not? One obvious reason to use document analysis is that it was the only source of information available to us due to insufficient resources for the conduction of the study. If we had other sources of information, we would surely have utilized them and validated our results.

There may be variety of document available such as "Faculty Profiles" in an educational institution that could provide data about their faculty members, but we decided to extract such data from a document called "Self-Study Reports"3 (SSR) due to provision of base-line requirements availability and also

${ }^{3}$ https://www.abet.org/accreditation/get-accredited/accreditation-step-by-step/ self-study-report 
because the data is well-structured and well organized. Note that completion of SSR document is a fundamental requirement for an institution when it applies for an ABET accreditation, therefore, document analysis of 27 different Self-Study Reports (for ABET accreditation) was performed for the data collection of faculty size, faculty professional development programs, ratio (instructor-students) and workload of the faculty members.

Our approach depicted in Figure $\mathbf{2}$ suggests that documents available in elementary schools, secondary schools and higher education institutes are analysed and assessment of retention and exit factors is performed. Our scope of study was only confined to those higher educational institutes which have acquired ABET accreditation because we can validate the extracted data from the literature against the data available in SSR and also can effectively compare among them. We can see that the factors of retention at schools and higher education were studied and these factors were then listed in the form of table as shown in Table 1, refer to the last column. Comparing these factors against the requirements of criteria 6 and 8, it will be well understood that the institutions with ABET accreditation, ensure by all means, all the factors needed for retention. Therefore, we expect high retention rate in such institutions.

\section{RESULTS AND DISCUSSIONS}

The document analysis technique was conducted to have a dataset from the institutional support and faculty criteria from the SSRs of different ABET accredited institutes as depicted in Table 2. As it can be seen from Table 2, out of 737 faculty members of 27 institutes, only $4(0.54 \%)$ faculty members left ABET accredited institutions. Based on the SSR's analysis, we could conclude that faculty retention is good in all these universities. This might be because they are institutions procuring ABET accreditation and thus might be following some standards to maintain their academic performance. Two cases out of 27 SSRs reveal that faculty members leave the academic institution either due to denial of tenure or probably due to higher student-to-faculty ratio. Further analysis reveal that

\section{REFERENCES}

Ajzen, I. (1991). The Theory of Planned Behavior. Organizational Behavior and Human Decision Processes. Organizational Behav. Hum. Decis. Process. 50, 179-211. doi:10.1016/0749-5978(91)90020-T

Anderman, E. M., Belzer, S., and Smith, J. (1991). Teacher commitment and job satisfaction: The role of school culture and principal leadership. Paper presented at the annual meeting of the American Educational Research Association. April 1991, Chicago. (ERIC Document Reproduction Service No. ED 375497).

Anderson, M. (2011). "Counseling Adults in Transition," in Linking Schlossberg, Äôs Theory with Practice in a Diverse World. Fourth Edition (Berlin: Springer Publishing Company).

Avalos, B. (2011). Teacher Professional Development in Teaching and Teacher Education over Ten Years. Teach. Teach. Edu. 27, 10-20. doi:10.1016/ j.tate.2010.08.007 average number of courses taught by a faculty in one semester is two to three.

\section{CONCLUSION AND FUTURE WORK}

In this research, we have explored the different influencing factors and criteria for retaining teaching staff at higher education institutes. These criteria are then evaluated against ABET (Accreditation Board of Engineering and Technology) accredited institutes criteria data of "faculty" and "Institutional support," to see the impact. Study shows that only very few faculty members leave the institution because of higher student-to-faculty ratio and/or denial of tenure.

Note that our investigation is not meant to be a generalized framework, rather an observation that may be considered by the faculty members to support in their decision-making process for their careers.

Since institutions applying for ABET accreditations, usually see themselves fulfilling the criteria and that's the reason for them applying for it. In the SSR usually the formal system is portrayed through procedural documents, however as informal systems (the way the system actually works) can be better judged through institutional visits, interview and observation techniques. In future we will investigate institutions which are relatively new, private and not accredited, to cross check the findings of the literature review.

\section{DATA AVAILABILITY STATEMENT}

The original contributions presented in the study are included in the article/supplementary material, further inquiries can be directed to the corresponding author.

\section{AUTHOR CONTRIBUTIONS}

All authors listed have made a substantial, direct, and intellectual contribution to the work and approved it for publication.

Barnes, L. L. B., Agago, M. O., and Coombs, W. T. (1998). Effects of Job-Related Stress on Faculty Intention to Leave Academia. Res. Higher Edu. 39, 457-469. doi:10.1023/A:1018741404199

Borman, G. D., and Dowling, N. M. (2008). Teacher Attrition and Retention: A Meta-Analytic and Narrative Review of the Research. Rev. Educ. Res. 78, 367-409. doi:10.3102/0034654308321455

Bowles, T., Hattie, J., Dinham, S., Scull, J., and Clinton, J. (2014). Proposing a Comprehensive Model for Identifying Teaching Candidates. Aust. Educ. Res. 41, 365-380. doi:10.1007/s13384-014-0146-z

Cockburn, A. D. (2000). Elementary Teachers' Needs: Issues of Retention and Recruitment. Teach. Teach. Edu. 16, 223-238. doi:10.1016/S0742-051X(99) 00056-6

Coldwell, M. (2017). Exploring the Influence of Professional Development on Teacher Careers: A Path Model Approach. Teach. Teach. Edu. 61, 189-198. doi:10.1016/j.tate.2016.10.015

Darling-Hammond, L. (2003). Keeping Good Teachers: Why it Matters, what Leaders Can Do. Educ. Leadersh. 60, 6-13. 
Dee, J. R. (2004). Turnover Intent in an Urban Community College: Strategies for Faculty Retention. Community Coll. J. Res. Pract. 28, 593-607. doi:10.1080/ 10668920490467242

Desselle, S. P., Zgarrick, D. P., and Ramachandran, S. (2021). What Are Academic Pharmacy Organizations Doing to Reward Performance and Retain Their star Faculty? Res. Soc. Administrative Pharm. S1551-7411, 00251-00255. doi:10.1016/j.sapharm.2021.07.007

Donitsa-Schmidt, S., and Zuzovsky, R. (2014). Teacher Supply and Demand: The School Level Perspective. Education 2, 420-429. doi:10.12691/ education-2-6-14

Espinoza, O., González, L. E., McGinn, N., Sandoval, L., and Castillo, D. (2020). Should Universities Train Teachers for Employability or for Effectiveness? Teach. Teach. Edu. 88, 102960. doi:10.1016/j.tate.2019.102960

García Torres, D. (2019). Distributed Leadership, Professional Collaboration, and Teachers' Job Satisfaction in U.S. Schools. Teach. Teach. Edu. 79, 111-123. doi:10.1016/j.tate.2018.12.001

Gardner, S. K. (2012a). "I Couldn't Wait to Leave the Toxic Environment": A Mixed Methods Study of Women Faculty Satisfaction and Departure from One Research Institution. NASPA J. About Women Higher Edu. 5, 71-95. doi:10.1515/1940-7890.1079

Goodwin, A. L., Low, E. L., Cai, L., and Yeung, A. S. (2019). A Longitudinal Study on Starting Teachers' Retention Intentions: Do Pre-teaching Work Experience and Length of Working Years Make a Difference? Teach. Teach. Edu. 83, 148-155. doi:10.1016/j.tate.2019.03.015

Gore, J., Lloyd, A., Smith, M., Bowe, J., Ellis, H., and Lubans, D. (2017). Effects of Professional Development on the Quality of Teaching: Results from a Randomised Controlled Trial of Quality Teaching Rounds. Teach. Teach. Edu. 68, 99-113. doi:10.1016/j.tate.2017.08.007

Heijde, C. M. V. D., and Van Der Heijden, B. I. J. M. (2006). A Competence-Based and Multidimensional Operationalization and Measurement of Employability. Hum. Resour. Manage. 45, 449-476. doi:10.1002/hrm.20119

Johnsrud, L. K., and Rosser, V. J. (2002). Faculty Members' Morale and Their Intention to Leave: A Multilevel Explanation. J. Higher Edu. 73, 518-542. doi:10.1353/jhe.2002.0039

Joram, E., Gabriele, A. J., and Walton, K. (2020). What Influences Teachers' "Buy-In" of Research? Teachers' Beliefs about the Applicability of Educational Research to Their Practice. Teach. Teach. Edu. 88, 102980. doi:10.1016/j.tate.2019.102980

Julion, W., Reed, M., Bounds, D. T., Cothran, F., Gamboa, C., and Sumo, J. (2019). A Group Think Tank as a Discourse Coalition to Promote Minority Nursing Faculty Retention. Nurs. Outlook 67, 586-595. doi:10.1016/j.outlook.2019.03.003

Kersaint, G., Lewis, J., Potter, R., and Meisels, G. (2007). Why Teachers Leave: Factors that Influence Retention and Resignation. Teach. Teach. Edu. 23, 775-794. doi:10.1016/j.tate.2005.12.004

Lo, M. C., Tolentino, J., Fazio, S. B., Vinciguerra, S., Amin, A. N., Dentino, A., et al. (2020). Identifying Solutions to Ambulatory Faculty Recruitment, Retention, and Remuneration in Graduate Medical Education: An AAIM Position Paper. Am. J. Med. 133, 386-394. doi:10.1016/ j.amjmed.2019.11.001

Long, J. C., and Morrow, J. (1995). Research analysis of professional development school graduates and traditional phase I and phase II graduates, in Annual Meeting of the Association of Teacher Educators. ERIC Document Reproduction Service No. ED 382 570. Available at: https://files.eric.ed.gov/fulltext/ ED382570.pdf

Piercy, F., Giddings, V., Allen, K., Dixon, B., Meszaros, P., and Joest, K. (2005). Improving Campus Climate to Support Faculty Diversity and Retention: A Pilot
Program for New Faculty. Innov. High Educ. 30, 53-66. doi:10.1007/s10755005-3297-z

Mayotte, G. A. (2003). Stepping stones to success: previously developed career competencies and their benefits to career switchers transitioning to teaching. Teaching and Teacher Education 19(7), 681-695. doi:10.1016/j.tate.2003.03.002

Ponjuan, L., Conley, V. M., and Trower, C. (2011). Career Stage Differences in Pretenure Track Faculty Perceptions of Professional and Personal Relationships with Colleagues. J. Higher Edu. 82, 319-346. doi:10.1353/jhe.2011.0015

Reynolds, A., Ross, S. M., and Rakow, J. H. (2002). Teacher Retention, Teaching Effectiveness, and Professional Preparation: a Comparison of Professional Development School and Non-professional Development School Graduates. Teach. Teach. Edu. 18, 289-303. doi:10.1016/S0742-051X(01)00070-1

Rosser, V. J., and Townsend, B. K. (2006). Determining Public 2-Year College Faculty's Intent to Leave: An Empirical Model. J. Higher Edu. 77, 124-147. doi:10.1080/00221546.2006.1177892110.1353/jhe.2006.0006

Schaefer, L., Long, J. S., and Clandinin, D. J. (2012). Questioning the Research on Early Career Teacher Attrition and Retention. Alberta J. Educ. Res. 58, 106-121. doi:10.11575/ajer.v58i1.55559

Tawafak, R. M., Mohammed, M. N., Arshahbin, R. b. A. A., and Romli, A. (2018). "Review on the Effect of Student Learning Outcome and Teaching Technology in Omani's Higher Education Institution's Academic Accreditation Process," in Proceedings of the 2018 7th International Conference on Software and Computer Applications, ICSCA 2018 (New York, NY, USA: Association for Computing Machinery), 243-247. doi:10.1145/3185089.3185108

Tawafak, R. M., Romli, A., Malik, S. I., and Shakir, M. (2020). IT Governance Impact on Academic Performance Development. Int. J. Emerg. Technol. Learn. 15, 73-85. doi:10.3991/ijet.v15i18.15367

Trimmer, K., Ward, R., and Wondunna-Foley, L. (2018). Retention of Indigenous Pre-service Teachers Enrolled in an Australian Regional university. Teach. Teach. Edu. 76, 58-67. doi:10.1016/j.tate.2018.08.006

Zavelevsky, E., and Lishchinsky, O. S. (2020). An Ecological Perspective of Teacher Retention: An Emergent Model. Teach. Teach. Edu. 88, 102965. doi:10.1016/ j.tate.2019.102965

Zhou, Y., and Volkwein, J. F. (2004). Examining the Influences on Faculty Departure Intentions: A Comparison of Tenured versus Nontenured Faculty at Research Universities Using NSOPF-99. Res. Higher Edu. 45, 139-176. doi:10.1023/B:RIHE.0000015693.38603.4c

Conflict of Interest: The authors declare that the research was conducted in the absence of any commercial or financial relationships that could be construed as a potential conflict of interest.

Publisher's Note: All claims expressed in this article are solely those of the authors and do not necessarily represent those of their affiliated organizations, or those of the publisher, the editors, and the reviewers. Any product that may be evaluated in this article, or claim that may be made by its manufacturer, is not guaranteed or endorsed by the publisher.

Copyright $\odot 2021$ Khan, Buhari, Tsaramirsis and Rasheed. This is an open-access article distributed under the terms of the Creative Commons Attribution License (CC $B Y)$. The use, distribution or reproduction in other forums is permitted, provided the original author(s) and the copyright owner(s) are credited and that the original publication in this journal is cited, in accordance with accepted academic practice. No use, distribution or reproduction is permitted which does not comply with these terms. 